\begin{tabular}{l|l|l|l}
$\begin{array}{c}\text { Case Reports in } \\
\text { Dematology }\end{array}$ & $\begin{array}{l}\text { Case Rep Dermatol 2011;3:1-4 } \\
\text { DOl: } 10.1159 / 000323663\end{array}$ & $\begin{array}{l}\text { Published online: } \\
\text { January 7, 2011 }\end{array}$ & $\begin{array}{l}\text { O 2011 S. Karger AG, Basel } \\
\text { ISSN 1662-6567 } \\
\text { www.karger.com/cde }\end{array}$ \\
\hline
\end{tabular}

\title{
Two Cases of Unilateral Ashy Dermatosis
}

\author{
Hisayoshi Imanishia, baisuke Tsuruta ${ }^{a}$ Hiromi Kobayashi ${ }^{\mathrm{a}}$ \\ Masamitsu Ishii ${ }^{a}$ Koichi Nakagawab \\ ${ }^{a}$ Department of Dermatology, Osaka City University Graduate School of Medicine,

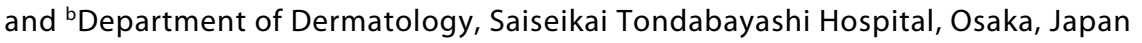

\section{Key Words}

Ashy dermatosis · Unilateral · Erythema dyschromicum perstans

\begin{abstract}
Ashy dermatosis is a typically asymptomatic disease of unknown origin that causes symmetrical gray spots to appear on the trunk and extremities. We report 2 cases of ashy dermatosis with unilateral distribution. To our knowledge, only 5 cases of ashy dermatosis with unilateral lesion have been reported so far. Case 1: an 11-year-old woman presented with asymptomatic slate-gray pigmented plaques on the left trunk and left upper arm. The skin biopsy specimen demonstrated a mild lymphohistiocytotic infiltrate in the upper dermis with epidermal and dermal melanosis. Q-Switched ruby laser did not improve such lesions. Case 2: a 21-year-old man was referred to our hospital because of asymptomatic slate-gray pigmented plaques on the left trunk and left upper arm. Histopathological findings were compatible with a mild lymphocytic infiltration with melanin incontinence in the upper dermis. The mechanism that governs unilateral distribution of ashy dermatosis, including in our cases, remains unclear.
\end{abstract}

\section{Introduction}

Ashy dermatosis is a typically asymptomatic disease of unknown origin that causes gray spots to appear on the skin. Patients with this disease have been called los cenicientos (the ash ones) due to the eruptions of oval, irregular or polycyclic, gray macules with erythematous, indurated, inflammatory borders $[1,2]$. With progression, the eruption develops a gray-blue color and loses the erythematous border, which is sometimes replaced with a hypopigmented periphery. Ashy dermatosis affects the trunk and extremities, and typically occurs symmetrically [2]. Here, we report 2 cases of unilateral ashy dermatosis. This distribution of eruption for ashy dermatosis is very rare. 


\begin{tabular}{l|l|l|l}
$\begin{array}{c}\text { Case Reports in } \\
\text { Demlitutology }\end{array}$ & $\begin{array}{l}\text { Case Rep Dermatol 2011;3:1-4 } \\
\text { DOI: } 10.1159 / 000323663\end{array}$ & $\begin{array}{l}\text { Published online: } \\
\text { January 7, 2011 }\end{array}$ & $\begin{array}{l}\text { O 2011 S. Karger AG, Basel } \\
\text { ISSN 1662-6567 } \\
\text { www.karger.com/cde }\end{array}$ \\
\hline
\end{tabular}

\section{Case Report}

\section{Case 1}

An 11-year-old female was referred to our hospital due to the appearance of asymptomatic slate-gray pigmented plaques on the trunk and left upper arm. She had no significant past or family history. The eruptions had appeared several years ago whereupon she had applied topical treatment of an ointment containing chlorhexidine gluconate with the intention to cure the plaque eruptions; however, they had not improved. Therefore, she visited our facility. On admission, a physical examination revealed slategray, irregular-shaped pigmented plaques on the left lateral abdominal region, left back, and left upper arm (fig. 1a, b). There were neither erythemas nor papules around the pigmented plaques. A laboratory test showed no abnormality. We performed a skin biopsy of the eruption on her back. Histopathological examination revealed a mild lymphohistiocytotic infiltrate in the upper dermis and epidermal and dermal melanosis ( $\underline{\text { fig. } 2 \mathrm{a}}$, b). Electron microscopic studies showed degeneration of basal keratinocytes and the presence of dermal melanophages (data not shown). We started a treatment of Q-switched ruby laser for the eruptions, but to date, we have not observed any improvement.

\section{Case 2}

A 21-year-old male visited our facility with asymptomatic, slate-gray, pigmented plaques that extended from the left abdomen to the left femur and had lasted for several years. There was no significant past or family history. Recently, the eruption had tended to spread. Examination of the skin showed an ashy-gray, irregular-shaped, pigmented area on the ventral aspect of the left abdomen that extended to the left femur (fig. 1c). There was neither atrophy nor induration of the skin associated with the eruption. Laboratory data was within normal limits. Microscopic examination of a biopsy specimen showed a lichenoid tissue reaction associated with a vacuolar change (fig. 2c, d). There was a mild infiltration of lymphocytes and a prominent melanin incontinence in the upper dermis. We followed up the case, but no changes have been observed.

In both of the cases we performed differential diagnoses for morphea, macular amyloidosis, fixed drug eruption, friction melanosis, pigmented contact dermatitis, lichen planus pigmentosus, and Becker's nevus $[3,4]$. We were able to exclude morphea due to the lack of sclerosis. We ruled out drug eruption because these patients had not taken any medicine. Pigmented contact dermatitis was unlikely, because these patients had not used any fabrics that had been processed with naphthol. The skin biopsy specimen demonstrated no amyloid deposition in the upper dermis; therefore, macular amyloidosis and friction melanosis were excluded. Becker's nevus was ruled out because the eruption was not hirsute and there was no increase of smooth muscle tissue. We excluded lichen planus pigmentosus because the eruptions were slate-blue in color, no lichen planus eruptions occurred in other sites, and there was no histological hypergranulosis. Therefore, we diagnosed these patients with unilateral ashy dermatosis.

\section{Discussion}

Ashy dermatosis, also known as erythema dyschromicum perstans, dermatosis cinecienta, or erythema chronicum figuratum melanodermicum, was first described by Ramirez in $1957[1,5]$. Ashy dermatosis is an acquired, typically asymptomatic, disfiguring skin disease that occurs most commonly in Latin American (particularly Mexican) and Asian populations [2]. The etiology is unknown. It exhibits a female predilection and can develop at any age; however, the majority of patients are under 30 years old [2]. Histologic examination of the active stage of ashy dermatosis is reported to demonstrate lichenoid dermatitis with vacuolization of the basal cell layer, occasionally colloid bodies, and increased epidermal melanin [1]. The dermal changes are reported to be edema of the papillary dermis, a moderate or mild lymphohistiocytic infiltrate, and dermal melanophages. In the inactive stage of ashy dermatosis, there is no vacuolization of the basal cell layer, and a diminished dermal infiltrate [1]. In addition, it was reported that patients of ashy dermatosis show idiopathic eruptive hyperpigmented macules, irrespective of the presence or absence of interface dermatitis histologically at the time of examination [6]. We assume that the eruptions in case 1 were inactive lesions, because the microscopic examination showed no vacuolization of the basal cell layer and less lymphohistiocytic infiltrate than 


\begin{tabular}{l|l|l|l}
$\begin{array}{c}\text { Case Reports in } \\
\text { Demlintoloyy }\end{array}$ & $\begin{array}{l}\text { Case Rep Dermatol 2011;3:1-4 } \\
\text { DOI: } 10.1159 / 000323663\end{array}$ & $\begin{array}{l}\text { Published online: } \\
\text { January 7, 2011 }\end{array}$ & $\begin{array}{l}\text { O 2011 S. Karger AG, Basel } \\
\text { ISSN 1662-6567 } \\
\text { www.karger.com/cde }\end{array}$ \\
\hline
\end{tabular}

inflammatory border. The histological finding in case 2 could be more similar to lichen planus, because it demonstrated prominent vacuolar change of basal layer and pigment incontinence. Therefore, we presume that the eruptions in case 2 correspond to the late active stage of ashy dermatosis. Most reported cases of ashy dermatosis have shown a symmetrical distribution of the eruptions. The two cases reported here are exceptional because the plaques were distributed unilaterally. To our knowledge, and according to a search in Japanese literature, only 7 cases of ashy dermatosis, including our 2 cases, have been reported that showed unilateral lesions [3, 4, 7-9]. Interestingly, all of the patients with unilateral distribution, including our patients, demonstrated a left-side distribution. The mechanism that governs plaque distribution remains unclear, but some speculated that it may be introduced by mosaicism. However, the eruptions did not occur along Blaschko's lines; therefore the data do not support that theory $[3,10]$. A greater number of case studies like ours is required to elucidate the pathogenesis of unilateral distribution of ashy dermatosis.

\section{Conflict of Interest}

We have no conflict of interest.
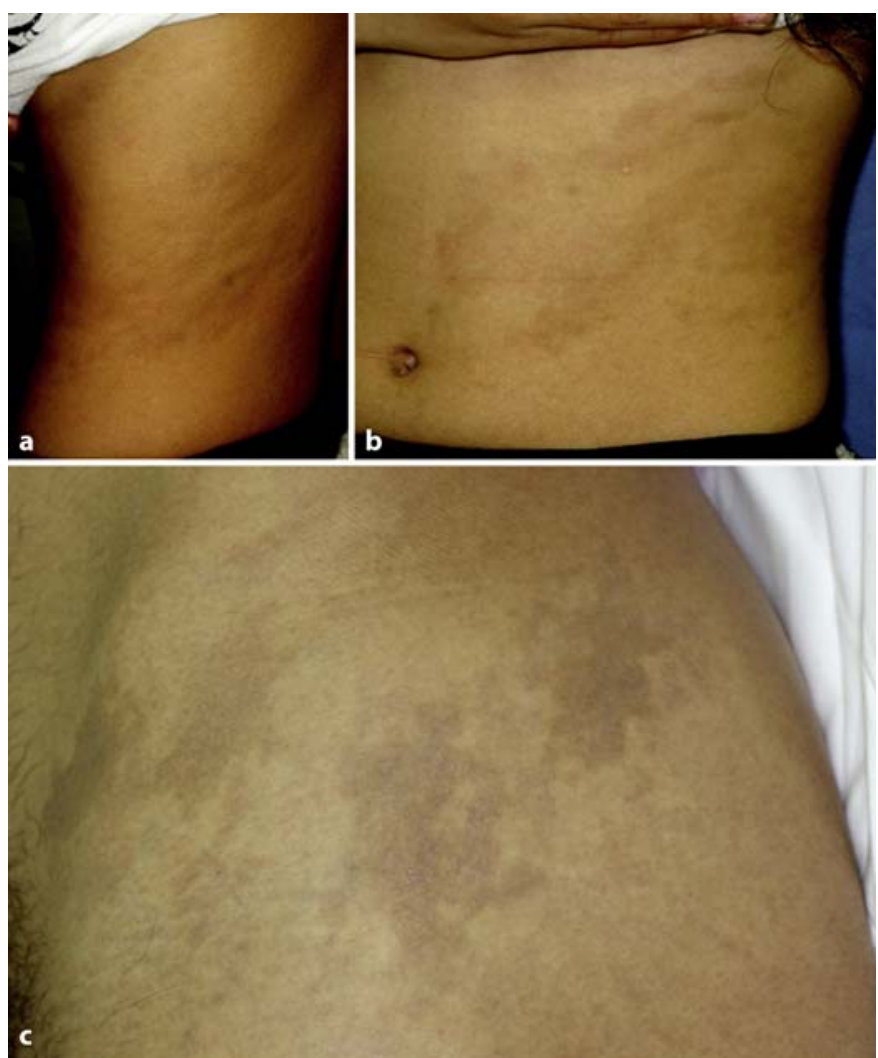

Fig. 1. a, b Asymptomatic slate-gray pigmented plaques on the left thigh (a) and left abdomen (b; case 1). c Ashy-gray pigmented area on the left femur (case 2). 


\begin{tabular}{c|l|l|l}
$\begin{array}{c}\text { Case Reports in } \\
\text { Dematoloyy }\end{array}$ & $\begin{array}{l}\text { Case Rep Dermatol 2011;3:1-4 } \\
\text { DOI: } 10.1159 / 000323663\end{array}$ & $\begin{array}{l}\text { Published online: } \\
\text { January 7, 2011 }\end{array}$ & $\begin{array}{l}\text { O 2011 S. Karger AG, Basel } \\
\text { ISSN 1662-6567 } \\
\text { www.karger.com/cde }\end{array}$ \\
\hline
\end{tabular}
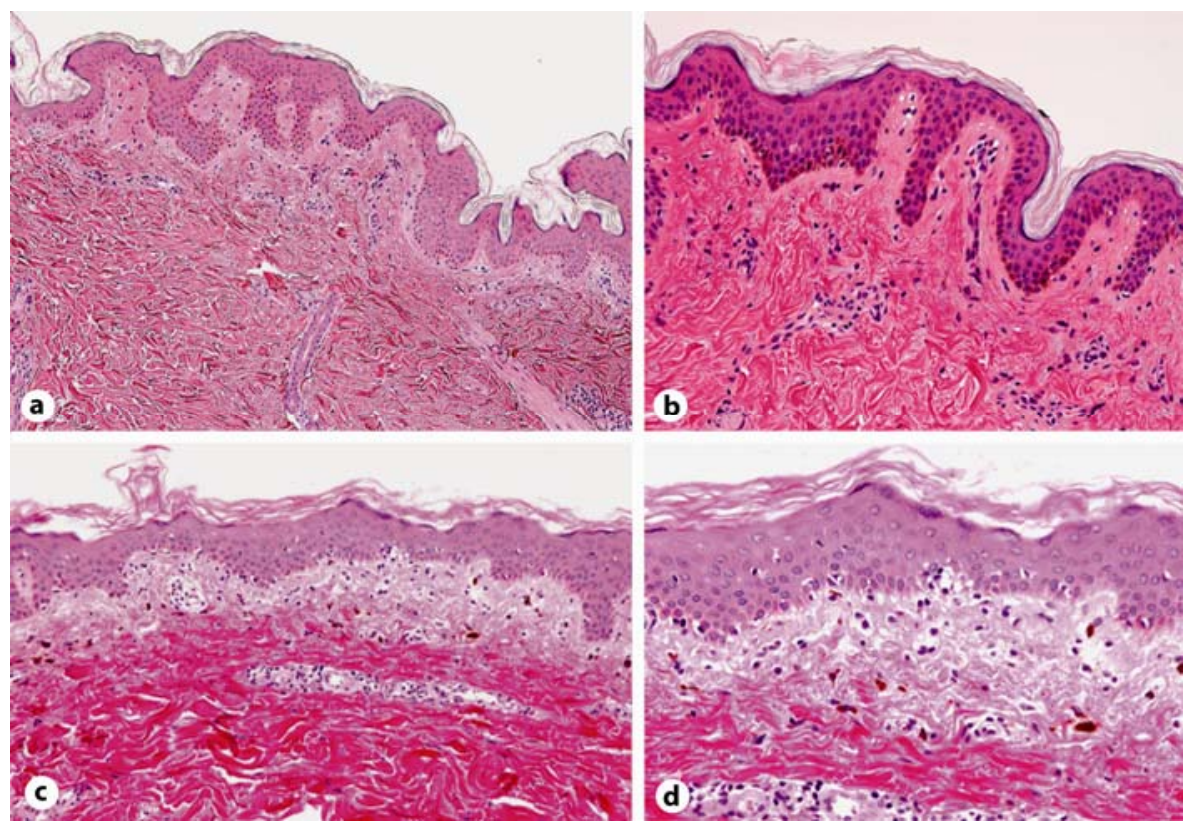

Fig. 2. a, b A punch biopsy from the back shows a mild lymphohistiocytotic infiltrate in the upper dermis and epidermal and dermal melanosis (case 1). c, $\mathbf{d}$ There is a lichenoid tissue reaction with vacuolar change and mild infiltration of lymphocytes and prominent melanosis in the upper dermis (case 2). HE, original magnification $\times 100(\mathbf{a}, \mathbf{c}), \times 200(\mathbf{b}, \mathbf{d})$.

\section{References}

1 Lapeere H, Boone B, Schepper SD, Verhaeghe E, Ongenae K, Geel NV, Lambert J, Brochez L, Naeyaert JM: Erythema dyschromicum perstans; in Wolff K, Goldsmith L, Katz SI, Gilchrest BA, Paller AS, Leffell DJ (eds): Fitzpatrick's Dermatology in General Medicine. New York, McGraw-Hill, 2008, vol 1, p 640.

2 Mckee PH, Calonje E, Granter SR: Erythema dyschromicum perstans; in Mckee PH, Calonje E, Granter SR (eds): Pathology of the Skin with Clinical Correlations. London, Elsevier Mosby, 2005, vol 1, pp 234-236.

-3 Yamamoto T, Matsuura H, Iwatsuki K, Sendo M: Unilateral ashy dermatosis. Nishinihon J Dermatol 2005;67:102-105.

4 Shirahama S, Yagi H, Takigawa M, Iwatsuki K: A case of ashy dermatosis with unilateral and band-like distribution. Acta Dermatol Kyoto 1994;89:15-17.

5 Ramirez CO: Los cenicientos: problema clínico. Memoria del Primer Congreso Centroamericano de Dermatología, San Salvador, 1957, pp 122-130.

6 Zaynoun S, Rubeiz N, Kibbi AG: Ashy dermatoses - a critical review of the literature and a proposed simplified clinical classification. Int J Dermatol 2008;47:542-544.

7 Akimoto R, Takeuchi Y, Saitoh M, Kurikawa Y, Itoh M: A infantile case of unilateral ashy dermatosis. Rinsho Derma 2001;43:435-438.

8 Palatsi R: Erythema dyschromicum perstans. A follow-up study from northern Finland. Dermatologica 1977;155:40-44.

9 Urano-Suehisa S, Tagami H, Iwatsuki K: Unilateral ashy dermatosis occurring in a child. Arch Dermatol 1984;120:1491-1493.

10 Fukuhara K, Arase S: A case of unilateral limited Darier’s disease. Rinsho Derma 2000;42:1955-1958. 